\title{
ANTV Corporate Social Responsibility Activities Review to Enhance Corporate Images in 2015 - 2017
}

\author{
Arbi Cristional Lokananta \\ Communication Faculty \\ Budi Luhur University \\ Jakarta, Indonesia \\ arbilokananta@yahoo.com
}

\begin{abstract}
This journal aims to find out Corporate Social Responsibility (CSR) activities in ANTV, including in which category of Corporate Social Responsibility (CSR) activities of ANTV, and what factors can improve ANTV image. The research method used is qualitative approach and descriptive explorative method with data collection obtained from direct observation and in-depth interview with informant. The results demonstrate the activities of Corporate Social Responsibility (CSR) in ANTV disaster relief, education and training assistance, health promotion, development assistance for public facilities and or infrastructure, aid of worship facilities, blood donation aid and other activities to improve ANTV corporate image.
\end{abstract} image

Keywords-corporate social responbility; ANTV; corporate

\section{INTRODUCTION}

Most companies or organizations now recognize the role of Public Relations (PR) is quite prominent in management decision making. Frequent PR managers, reporting or in touch with top management. For the simple reason that the PR is the interpreter (interpreter) of management, so PR should know what management thinks every moment of any real public issues.

Fraser P. Seitel in his book The Practice Public Relations says that in recent years PR has developed theoretical framework as a management system. Grunig and Hunt suggest that public relations managers act on what is called an international theoretical boundary role (playing a role on the border); they function at the edge of a company or organization with its internal and external public. In other words, PR managers must place their feet inside the company and other legs outside the company (public).

PR conducts mutual communication between an organization or institution and its public to create mutual understanding (public relations) for the creation of objectives, policies and steps and actions of such Institution or organization. They are aimed at developing the public goodwill and to gain a favorable public opinion or to create cooperation based on harmonious relationships with the public.
Basically, any organization or company that embraces a shareholder oriented philosophy would assume the presence of a PR function in management as absolute. PR is fundamentally the responsibility of top management. PR functions can be expected as "eyes", "ears", and "right-handed" top management of the company. Scope of public relations tasks: (a) into: (1) fostering the mental attitude of employees in order to grow in compliance, obedience, and dedication to the institution or company where they work; (2) fostering a healthy and dynamic spirit of the corporation or group; (3) encourage the growth of awareness of institutions or companies, and (b) to the outside: to strive for positive public attitudes and image of all policies and actions of the organization, agency or company.

PT Cakrawala Andalas Televisi (ANTV) present as a private television station in Indonesia that presents a variety of entertainment quality, interesting and add insight and knowledge of the people of Indonesia. Initially ANTV is a local television station that broadcasts in the area of Lampung and surrounding areas.

With the local broadcasting permit ANTV aired for five hours a day, then ANTV received the National Broadcasting License from the Minister of Information of RI with no. 207 / RTF / K / I / 1993 dated 30 January 1993. Ten days after the permit was issued ANTV can broadcast nationally. Exactly March 1, 1993 for the first time ANTV produced its own program in the form of actual news coverage of the General Session of the DPR / MPR. At that time ANTV managed to broadcast live coverage of the important activities of statehood. That special moment that was made as the birthday of ANTV, now more than 23 years ANTV accompany the audience with the best programs.

Being the best family television channel for the whole Indonesian family. ANTV's mission to achieve that vision is to provide the best quality programs of every family member to support the development of the Indonesian Nation's character with the spirit of creativity and innovation of teamwork and corporate governance.

PT. Cakrawala Andalas Televisi committed to quality policy by making sustainable improvements in: 
- $\quad$ Seeking the best to satisfy the customer.

- Empowering employees' ability in the direction of professionalism.

- $\quad$ Implementing ISO 9001: 2008.

- Integrate all processes within the unit to achieve optimum efficiency and effectiveness.

- Conduct a continuous review and improvement of Standard Operating Procedures so that ANTV can operate more efficiently.

PR ANTV is better known as Corporate Communication in which there are divisions one of them corporate social responsibility (CSR) consisting of three staff. ANTV's social responsibility through its CSR team focuses on several themes, such as Health, Education, and Economic Development. The ANTV CSR program is undertaken by the company to make social investments as well as reduce the business risks of the company as well as to improve the welfare of the community around the operation area (all over Indonesia). Based on the background of the problem, then formulated the problem that is: how corporate social responsibility (CSR) ANTV in improving ANTV image during the period of 2015-2017? The formulation of this issue is outlined as a research question as follows:

What are ANTV CSR activities?

- Included in which category of ANTV CSR activities?

- What factors can improve ANTV image?

Thus the purpose of the research is to:

- Knowing CSR activities in ANTV

- Identify CSR activities category in ANTV

- $\quad$ To know factors that can improve ANTV imaging through CSR activities

\section{THEORETICAL FRAMEWORK}

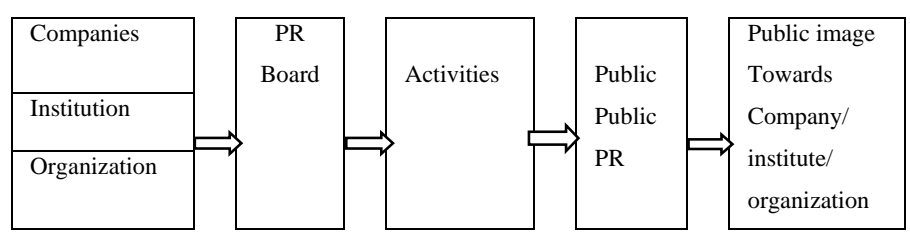

The above chart is a form of public relations orientation, i.e. image building (image building), can be seen as a communication model in the PR. Discussion of the image mentioned by Frank Jefkins in [1, p. 114] that in general the image is defined as the impression of a person or an individual about an emerging as a result of his knowledge and experience. Furthermore, the image according to Rachmat in [1, p. 114], is a description of reality and does not necessarily correspond to reality, image is the world according to perception. So the image is a person's view of the reality of everything that has or has not happened to his life.

The process of image formation will eventually produce a certain attitude, opinion, response or behavior. To find out how the image of a company or institution in the public mind needed a study. Through research, companies can know for sure the public attitude towards the institution, knowing what I liked and what the public does not like.

\section{RESEARCH METHODS}

The method used is qualitative with the type of descriptive qualitative writing is explorative. In qualitative research known some technique or method of data collecting, among others: interview, observation, FGD, and case study. In this study the author tries to describe the results of this study thoroughly from a condition or symptoms that arise by using words written or spoken from people who have observed behavior based on interviews that have been done. This writing method uses explorative qualitative description type in which the author describes the results of in-depth interviews on the subject of Writing.

To obtain writing data, the author makes direct observations to the ANTV CSR team. Writing data was analyzed based on the group's PR communications theory according to Frank Jefkins's Image of observations and interviews. This writing takes place in ANTV - Rasuna Epicentrum Lot 9 Complex Jl. H.R. Rasuna Said, Karet Kuningan Setiabudi, South Jakarta - Indonesia 12940. Data source of this writing is ANTV CSR program from 2015 2017. Writing Data is the result of observation and interview conducted directly by the author and other data library owned.

There are two types of data that author use in this research, namely primary data and secondary data:

\section{A. Primary data}

Primary data according to [2, p. 137], is a source of data that directly provide data to data collectors. The primary data collection in this research is through direct interview with ANTV CSR team. Researchers determine the key informants and informants. While the interview technique is done in-depth interview (indepth interview) continuously with Corporate Communication team as PR ANTV especially CSR team.

\section{B. Secondary Data}

Secondary data according to [2, p. 137], is data obtained by reading, studying, and understanding other media sourced from the literature, books, and company's documentation. 
Analysis of data obtained from respondents, the authors collect and analyze existing data. The data collected in qualitative research takes the form of words or images rather than numbers. The results of written research contain excerpts from the data to illustrate and provide evidence.

\section{RESEARCH RESULTS}

In the informant who the author interviewed and conducted observations, it was found that the activities of CSR ANTV as follows:

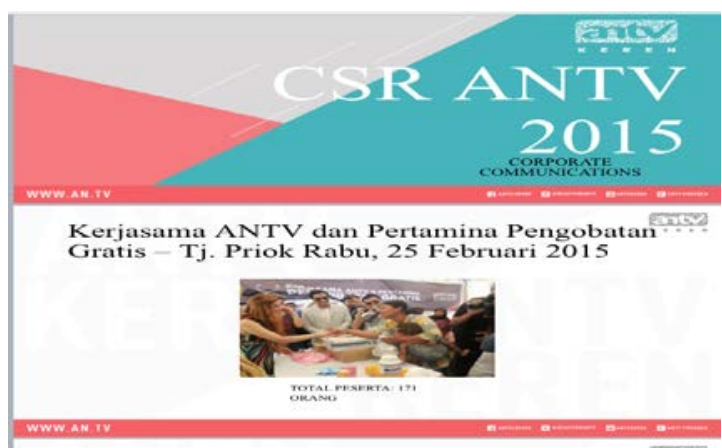

Donor Darah Di ANTV - 2 Maret 2015

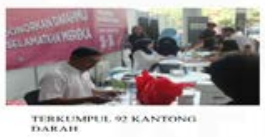

Pengobatan Gratis ANTV - Yogya, 17 Maret .... 2015

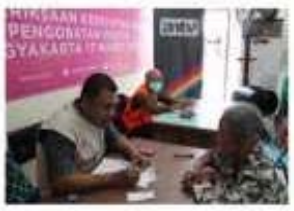

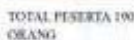
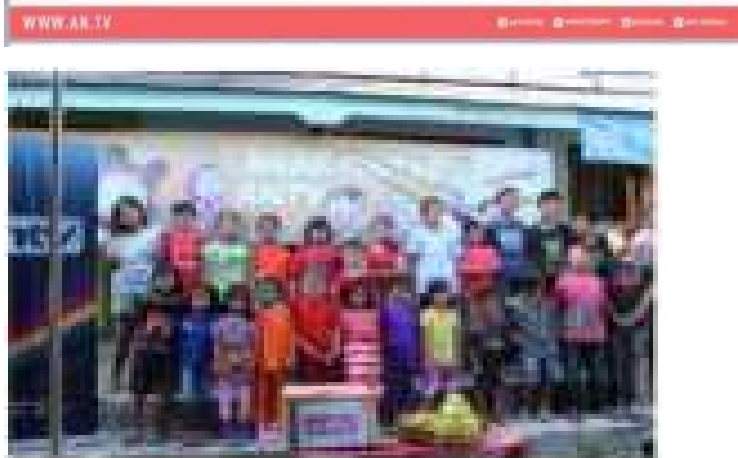
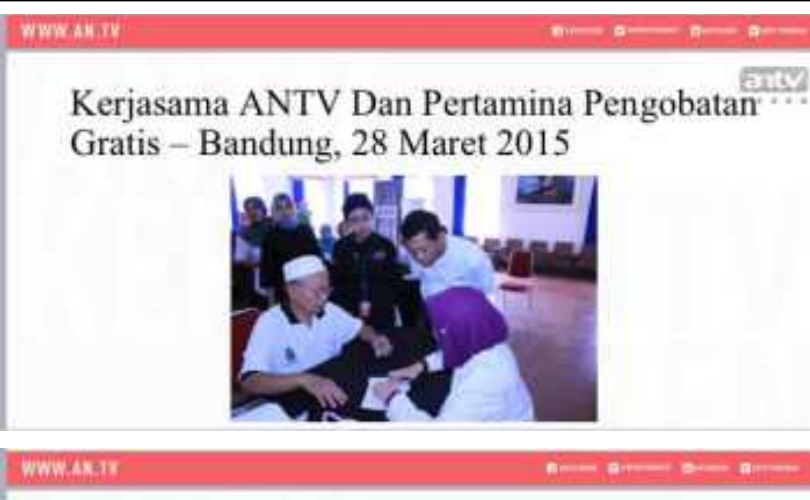

Kerjasama ANTV Dan Pertamina, Pengobatan Gratis - Jatinegara, 6 Mei 2015
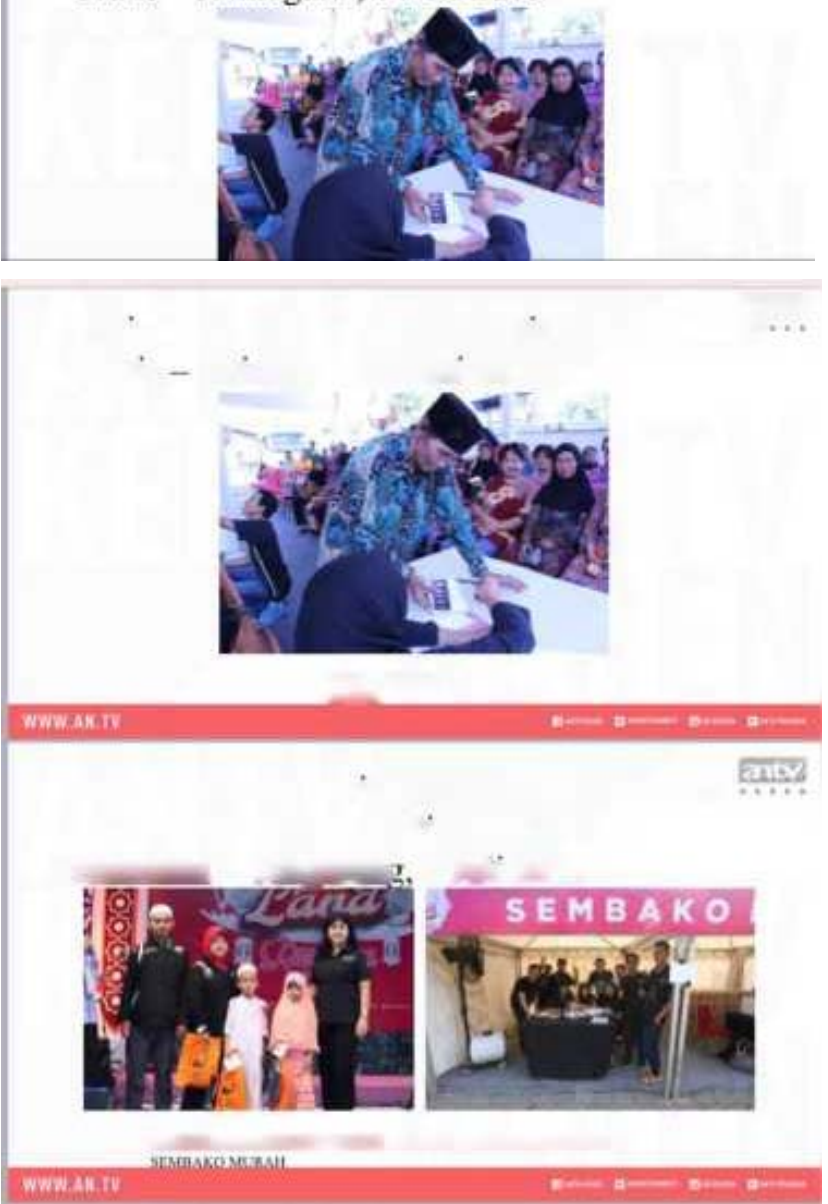

Wwask 


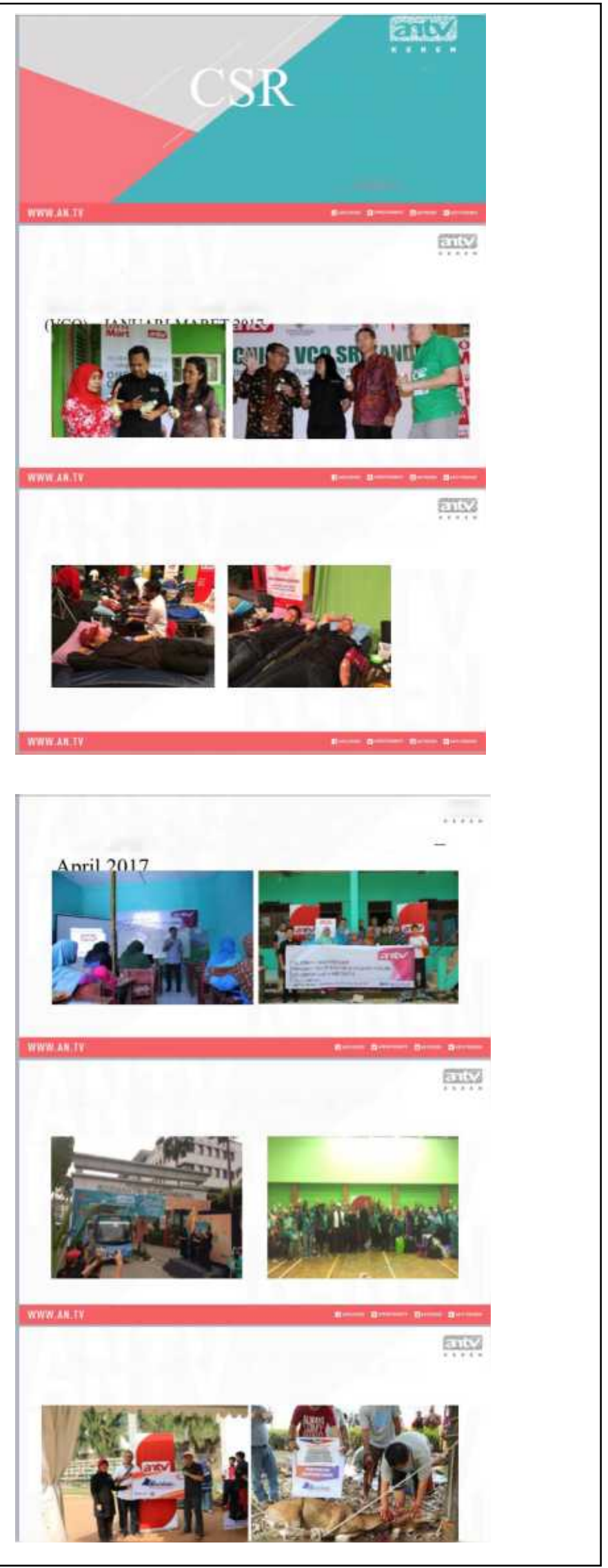

\section{DISCUSSION}

CSR (Corporate Social Responsibility) ANTV has been implemented then is expected to be a business strategy which is inherent in the company for maintain or enhance competitiveness through reputation and brand loyalty product (loyalty) or company image in order to become competitive advantage of the company which is difficult to imitate competitor. On the other hand, the desire of the consumer to buy products based on criteria- criteria based on values and ethics, is expected to change behavior consumers in the future [3].

\section{CONCLUSION}

Based on the results of the study, then the conclusion can be obtained as follows:

- Program of CSR activities held ANTV among others namely disaster victim assistance nature, educational assistance and training, improvement health, assistance development of facilities and / or public infrastructure. Help facilities of worship, and assistance blood donors.

- CSR activity category in ANTV includes creating one the ecosystem benefit all parties (true win win situation), consumers get superior product friendly environment, ANTV too get the appropriate profit which will eventually returned to hand society not directly.

- CSR Activities in ANTV within improve the company image has been proven with ANTV gets The Best Marketing Public Relations Program 2017 in Indonesia PR of The Year by Magazine MIX \& SWA [4].

\section{REFERENCES}

[1] S. Soemirat and E. Ardianto, Dasar - Dasar Public Relations [Basics of Public Relations]. Jakarta: PT.Remaja Rosdakarya, 2010.

[2] Sugiyono, Metode Penelitian Kuantitatif Kualitatif dan R\&D [Quantitative, Qualitative, and R\&D Research Methods]. Bandung: Alfabeta, 2008.

[3] R. M. Oktaviani, Corporate Social Responsibility dan Strategi Perusahaan: Perspektif Pendekatan Kualitatif (Studi Kasus pada PT Apac Inti Corpora Bawen Semarang) [Corporate Social Responsibility and Company's Strategy: Qualitative Approach Perspective (Case Study of Apac Inti Corpora, Inc. Bawen Semarang)], 2012, [Online]. Available:

http://eprints.unisbank.ac.id/1311/1/CORPORATE\%20SOCIAL\%20RE SPONSIBILITY\%20DAN\%20STRATEGI\%20PERUSAHAAN_\%20P ERSPEKTIF\%20PENDEKATAN\%20KUALITATIF\%20\%28STUDI\% 20.pdf. [Accessed Dec. 19, 2017].

[4] “Tentang Kami ANTV [About us: ANTV]," [Online]. Available: https://www.antvklik.com/corp/about. [Accessed Dec. 19, 2017]. 